\title{
Intercalary Months and Interest-bearing Loans in Babylonia. A Promissory Note from the Egibi Archive
}

\section{Zoltán Csabai*}

* - Department of Ancient History, University of Pécs. Email: csabai.zoltan@pte.hu

\begin{abstract}
In this paper a cuneiform economic document from the Egibi archive is investigated. The text is a promissory note from Babylon and was written in an intercalary month in the 6th century B.C. The study discusses how interest in the Babylonian interest-bearing loans worked and how the existence of intercalary months, a peculiarity of the Babylonian calendar, had an effect on this system.
\end{abstract}

Keywords: Egibi archive, Neo-Babylonian economic texts, interest-bearing loans, intercalary months

Cite as Csabai, Z. 2020: Intercalary Months and Interest-bearing Loans in Babylonia. A Promissory Note from the Egibi Archive. Hungarian Assyriological Review 1, 61-73.

https://doi.org/10.52093/hara-202001-00005-000

(ㄷ)(i) This is an open access article distributed under the terms of the Creative Commons Attribution License, which permits unrestricted use, distribution, and reproduction in any medium, provided the original author and source are credited.

The Mesopotamian calendar is characterized by the use of intercalation. To reconcile the difference between the twelve months lunar (354 days, consisting of 29- and 30-days months) ${ }^{1}$ and the solar calendar (ca. 365 days), intercalary months were inserted. ${ }^{2}$ Before the $1^{\text {st }}$ millennium B.C., the insertion of intercalary months was not regular, systematic and predictable. ${ }^{3}$ From the Late Achaemenid period on, and especially from the last decades of the $5^{\text {th }}$ century B.C. the 19-year cycle became regular. ${ }^{4}$ Economic and administrative sources are rarely considered in the study of intercalation; however, they can prove to be useful in identifying intercalary months as well as in examining the systematic nature of their insertion. ${ }^{5}$

In this brief study, a cuneiform economic text from the Early Achaemenid period is put under scrutiny. A special feature of the tablet, recorded in the reign of Darius I, is the fact that it was written in an intercalary month - it may even be assumed that it was the intercalary month itself that led to the drawing up of this document.

1 There is no example of a 31-day month in the regular calendars from Mesopotamia.

2 Steele 2011, 475-478. For the schemes of intercalation in the series MUL.APIN see Hunger - Pingree 1999, 75-79; new perspectives on intercalation schemes are in Ratzon 2016.

3 Hunger 1977. On Neo-Babylonian and Achaemenid intercalations see Steele 2007, 137-140.

4 In the 19-year cycle there was an intercalary month in each of the $1^{\text {st }}, 3^{\text {rd }}, 6^{\text {th }}, 9^{\text {th }}, 12^{\text {th }}, 14^{\text {th }}$, and $17^{\text {th }}$ years. With the exception of the $12^{\text {th }}$ year when intercalary Ulülu (i.e., second sixth month) was inserted, an intercalary Addaru (i.e., second twelfth month) was added. In the first three cycles the presence of intercalary Ulūlu is uncertain, but from cycle 419/418-401/400 B.C., this system can be observed. For details see Ossendrijver 2018, 139-140 and 147-149.

5 For examining the relationship between economic sources and intercalation see recently Stratford 2015 (on Old Assyrian evidence). 
BM 31230 is a promissory note written in the form of an $u^{\prime} i l t u .{ }^{6}$ It describes a silver loan of five minas (ca. $2.5 \mathrm{~kg}$ ) that was to be paid back with an interest of $20 \%$. It was the intercalary month along with the clause on interest payment that called my attention to this document. M. Van De Mieroop made noteworthy statements about how intercalary months and interest-bearing loans are related. Van De Mieroop assumed that the irregular insertion of intercalary months in the Mesopotamian calendar is one of the reasons why the interest specified in economic texts cannot be understood as the annual rate of interest, requiring the debtor to pay interest on the basis of the amount of loan and the loan period; instead, the interest was to be added to the loan in one sum. ${ }^{7}$ According to Van De Mieroop, this theory of loan provides a solution for handling anomalies caused by the unexpected insertion of intercalary months in the calendar. By contrast, P. Vargyas had put forth an opposing view drawing on Babylonian sources from the first millennium B.C. ${ }^{8}$ Vargyas proposed that the ancient Babylonians employed a sophisticated formula to calculate interest rates and their advanced mathematical knowledge enabled them to calculate the interest to be paid even when an intercalary month was inserted in the calendar. Van De Mieroop refused to accept Vargyas's proposal. ${ }^{9}$ Therefore, in the present paper I will examine interest-bearing loans written in intercalary months, including the text analyzed here, in an effort to take a side in the debate.

There are sixteen published documents from $1^{\text {st }}$ millennium B.C. Babylonia that deal with interest-bearing loans and were recorded in intercalary months. They date from 653 B.C. to 269 B.C., but the majority of them were written between 621 B.C. and 499 B.C. There are more documents dated to intercalary Addaru (month XII2) than to intercalary Ulūlu (month VI2); this is not an unusual tendency, since there were more intercalary Addaru than intercalary Ulūlu months, and more interest-bearing debt notes were made in the second half of the Babylonian year. ${ }^{10}$ Four loan documents include antichretic pledge (Zinsantichrese). ${ }^{11}$ Two of them solely denote antichretic pledge: a servant is offered to the creditor in one document ${ }^{12}$ and a house in the other ${ }^{13}$ to pay off the equivalent of the entire interest to be paid. A third text documents a loan of a large amount of money: 600 shekels of silver. In this case, the income deriving from the rental of the assigned house covered half of the loan's interest, so only the other half of the loan bore interest. ${ }^{14}$ In the fourth case, the text sets out a deferred interest-bearing loan, the accruing of interest begins two

$6 \quad$ On the Neo-Babylonian u'iltu see in particular Petschow 1956; further Oelsner 2001, 289-305; Jursa 2002, 197-203; Wunsch 2002, 224-230; Oelsner - Wells - Wunsch 2003, 949-961.

7 Van De Mieroop 1995, 360 and 2005, 29.

8 Vargyas 2000, 1102.

9 Van De Mieroop 2005, 361 n. 41.

10 See Csabai 2008, 205-207. A year is not understood in terms of a calendar year but corresponds to the agricultural year (starting at harvest time and ending at the next harvest).

11 In the case of antichretic pledge, the debtor offered a source of regular income to the creditor to substitute interest payments. The most common example of such substitution is the assignment of the right to rent out a house in order to settle interest payment during the interest period.

12 TMH 2/3 115 (549 B.C.).

13 TCL 1221 (605 B.C.).

14 Ellis 1984 no. 1. (653 B.C.) The sum of the loan amounted to ten minas of silver. For five minas the debtor had to pay 5 shekels per mina annually (i.e., an interest rate of 8.33\%). The other five minas of silver were covered by the assignment of a house to the creditor, as antichretic pledge (i.e., its annual rent amounted to 25 shekels). 
months later. ${ }^{15}$ There is also a so-called hubuttu loan ${ }^{16}$ among the sources; however, it is not a loan of silver but that of barley. ${ }^{17}$ Thirteen of the texts document interest-bearing loans, on one tablet the sign recording the rate of interest is broken, ${ }^{18}$ and in another document the interest rate is uncertain. ${ }^{19}$ The following rates of interest occur: $8.33 \%,{ }^{20} 12.5 \%,{ }^{21} 16.66 \%{ }^{22}$ and $20 \% .{ }^{23}$

Despite the limited number of available texts, the beginning of the interest period shows significant variation. There are three deferred interest-bearing loans, one of them was discussed earlier (Jursa 1998 no. 16). In the other two promissory notes, the interest began to run on the first day of the month following the conclusion of the agreement (Dar 556 and partially BM 31230). In the other nine loans, the interest started to run in the intercalary month when the document was written. There is at least one antedated loan in which the initial interest payment was due on the first day of intercalary Addaru, the month when the text was written. ${ }^{24}$ Two tablets expressly required the debtor to pay interest from the very day on which the loan document was drawn up. ${ }^{25}$ Seven cuneiform texts prescribed interest payment in the simplest, most common form, ${ }^{26}$ starting on the date of the debt note.

Interest-bearing loans made in intercalary months do not include any special clause implying that loans written in intercalary months entailed extraordinary legal or administrative conditions to be observed by contracting parties. Legal terms and conditions seem to have been identical in regular and in intercalary months in the Neo-Babylonian and Achaemenid periods. Nonetheless, the fact that eleven of the eighteen loan contracts required the debtor to start accruing interest in the intercalary month means that the intercalary month was included in the interest period.

\section{BM 31230}

The following document (Fig. 1) may facilitate us to take a side in the debate. Previous studies on Neo-Babylonian loans revealed that promissory notes had sometimes been renewed or rewritten, which is also true for the loan recorded in BM 31230. Fortunately, the original promissory note (Dar 170) is also preserved, allowing us to compare the two texts and investigate the differences. A loan was renewed, as a rule, in the case of paying arrears, changes in the conditions, or changes

15 Jursa 1998 no. 16 (269 B.C.). The creditor required three items as security for a loan of a relatively small amount of silver (beside an antichretic pledge both the debtor's wife and son secured the debt).

16 The exact legal and economic meaning of hubuttu (as well as hubuttūtu and hubuttātu) loans is still unclear, see, for instance, Skaist 1994, 52-56; Westbrook 2003b, 403; Slanski 2003, 510; on the Neo-Babylonian material see Petschow 1956, 15 n. 31; Shiff 1988; Oelsner - Wells - Wunsch 2003, 950; and on loans from the Sîn-uballit archive Cseke 2014, 573-574.

17 VS 335 (562 B.C.): 1.1.0.0. (216 litres of) barley, in Ālū Bānītūya.

18 Kessler 1991 no. 88: 1' (603 B.C.).

19 YOS 19 26: 5 (546 B.C.).

20 Ellis 1984 no. 1: 3-4 (653 B.C.) and BE 8/1 157: 4-5 (621 B.C.).

21 OECT 12 A 91: 4-5 (574 B.C.).

22 Hunger 1970 no. 17 III: 26-35 (598 B.C.).

23 Hunger 1970 no. 17 II: 6-20 (600 B.C.); Nbn 438 (546 B.C.); Nbn 678 (543 B.C.); Cyr 219 (532 B.C.); BM 31230 (516 B.C.); Dar 556 (499 B.C.); Jursa 1998 no. 16 (269 B.C.).

24 Nbn 678 was written on the $16^{\text {th }}$ of intercalary Addaru and the interest started to run on the first day of the same intercalary Addaru.

25 Hunger 1970 no. 17 II: 6-20 and III: 26-35.

26 E.g., Nbn 438: 5-7 ša arḩi ina muḩhi 1 manê 1 šiqil kaspi ina muḩhīšu irabbi 'each month one shekel of silver per one mina will accrue against him'. 
in the amount of loan. None of these, however, was the case for this tablet.

BM 31230 belongs to the Egibi archive, the largest, most famous archive in the Neo-Babylonian period. ${ }^{27}$ It concerns the main protagonist of the fourth generation, a certain Marduk-nāșir-apli. ${ }^{28}$ These two documents were not included in the previous edition of the archive. Dar 170 has already been available in autograph and transliteration, ${ }^{29}$ thus only a translation of this text is presented here. In the case of BM 31230, the autograph (Fig. 1), the transliteration and the translation are published in the present study for the first time.

\section{Dar 170}

promissory note for silver

Babylon, Dar. I 16-VI-5 (September 517 B.C.)

\section{Translation}

${ }^{1}$ Five minas of ginnu-silver of $1 / 8$ alloy, which (is used) in trading (lit. 'giving and receiving'), (are) ${ }^{3}$ owed to Marduk-nāșir-apli, son of Itti-Marduk-balāțu, descendant of Egibi by Nabû-apla-iddin, ${ }^{5}$ son of Nabû-ēṭir, descendant of Isinnāya.

Each month one shekel of silver per one mina will accrue against him (i.e., $20 \%$ interest). ${ }^{7}$ Apart from a previous / an earlier debt [owed by?] Nabû-apla-iddin who was present(?).

${ }^{9}$ Witnesses: Arrabu, descendant of Šangû-[...]; [...], descendant of Atû; ${ }^{11}[\ldots$, son of] Marduk-nāșir-apli, [descendant of ...]; Marduk-balāssu-iqubi, ${ }^{13}$ [son of Bān]īya, descendant of Nabaya; [Nergal-ušal]lim?, son of Mušēzib-Marduk, ${ }^{15}$ descendant of Nappāḩu; Nabû-apla-iddin, son of Iddin-Nabû, descendant of Dābibī.

Scribe: Bulțāya, ${ }^{17}$ son of Nabû-apla-iddin, descendant of Isinnāya.

(Written in) Babylon, (on the) $16^{\text {th }}$ day of Ulūlu, the $5^{\text {th }}$ year (of the reign) of ${ }^{19}$ Darius (I), king of Babylon and (of) the lands.

\section{Notes}

(1-2) The expression kaspu ša ginnu was identified by Vargyas as Darius' coined silver siglos. ${ }^{30}$ However, with the exception of Powell, ${ }^{31}$ his theory remains largely unaccepted in the field of the Neo-Babylonian studies. ${ }^{32}$ Instead, M. Jursa's opinion has been followed since then. ${ }^{33}$ The clause kaspu ša ginnu ša nadāni u maḩāri 'ginnû-silver, which (is used) in trading (lit. "giving and receiving”)' has been subject to various investigations. ${ }^{34}$

27 For an overview of the Egibi archive see Wunsch 1999a; 1999b; 2007. For detailed discussions of parts of the archive see Wunsch 2000 and Abraham 2004.

28 The Marduk-nāșir-apli file of the archive was discussed in detail by Abraham (2004).

29 Joannès 2000/2002.

30 Vargyas 2001, 24-34. See in detail Vargyas 1999.

31 Powell 1999, 21-23.

32 For the sigloi, with a review of previous studies, see Corfù 2010.

33 Jursa et al. 2010, 480-485.

34 Vargyas 2001, 21-24 and Jursa et al. 2010, 488-489, respectively. 
(3-5) The creditor, Marduk-nāșir-apli/Itti-Marduk-balāțu//Egibi is the main protagonist in the fourth generation of the Egibis. ${ }^{35}$ The debtor, Nabû-apla-iddin/Nabû-êțir//Isinnāya is otherwise unattested in the published tablets assigned to the archive of Marduk-nāșir-apli.

(6-7) This is one of the most common interest clauses in the Neo-Babylonian records, it stipulates a yearly $20 \%$ rate of interest on a monthly basis.

Witnesses and the scribe: I restore six witnesses in Dar 170.

Nergal-ušallim/Mušēzib-Marduk//Nappāhnu occurs both in Dar 170 and BM 31230. ${ }^{36}$

Bulțāya/Nabû-apla-iddin//Isinnāya was the scribe who wrote both tablets. Presumably, he was the son of the debtor. From the Neo-Babylonian period we know many loan contracts, the scribe of which belonged to the debtor's family ${ }^{37}$ sometimes the scribe was the debtor himself. ${ }^{38}$

\section{BM $31230(=\text { Bertin 2067 })^{39}$}

promissory note for silver

Babylon, Dar. I 4-XII2-5 (March 516 B.C.)

obv. 1) [5] MA.NA KÙ.BABBAR šá gìn-nu šá na-da-nu

2) [u m]a-ḩa-ri šá IdšÚ-PAB-A A-šú šá ${ }^{\mathrm{K}} \mathrm{II}^{\mathrm{d}} \mathrm{A}$ AMAR.UTU-DIN

3) [A ${ }^{\mathrm{I}}$ e-gi-bi ina UGU ${ }^{\mathrm{Id}} \mathrm{NÀ}-\mathrm{A}-\mathrm{MU}$

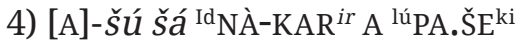

5) ul-tu U $\mathrm{U}_{4}$ 1.KAM šá itišE KI ${ }^{\mathrm{iti}} \mathrm{BÁRA}$

6) šá ITI ina UGU ${ }^{h i} 1$ ma-né-<e> 「1’ [G]ÍN KÙ.BABBAR

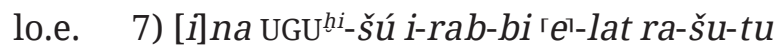

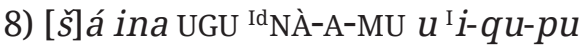

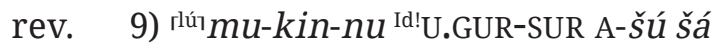

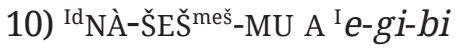

11) IdU.GUR-GI A-šú šá I KAR-d ${ }^{I}$ Š A ${ }^{\text {lúSIMUG }}$

12) lúUMBISAG ${ }^{\mathrm{I}} b u l-t ̣ a-a$ a-šú šá Id NÀ-A-MU

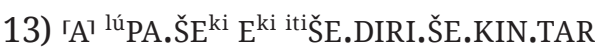

14) ${ }^{\circ} \mathrm{U}_{4} 4$ 1.KAM MU 5.KAM ${ }^{\mathrm{I}}$ da-ri-muš

15) LUGAL $E^{k i} u$ KUR.KUR

35 Abraham 2004, 13-16.

36 Nergal-ušallim(=Šullumu)/Mušēzib-Marduk//Nappāhnu appears as witness at least six more times in the Marduk-nāșir archive: Abraham 2004 no. 85 (BM 41449); no. 97 (= Dar 182); no. 100 (= Dar 213); no. 102 (= Dar 268); no. 110 (= Dar 338); no. 112 (= Dar 345). It is especially interesting that four of these texts were written during the fifth year of Darius I: Dar 170 and BM 31230 which are discussed here, as well as Abraham 2004 no. 85, and no. 97). In all of these four texts he is called Nergal-ušallim. In the other four texts from the $6^{\text {th }}$ (no. 100), $10^{\text {th }}$ (no. 102), $12^{\text {th }}$ (no. 110), and $13^{\text {th }}$ (no. 112) years of Darius I his name appears as Šullumu. Therefore, I suppose that the tablet Abraham 2004 no. 85, which is broken at the date (see Abraham 2004, 364), was written in the $5^{\text {th }}$ year of Darius I, too.

37 Some examples: Nbk 68: the debtor is Nabû-gāmil/Rihētu//Sîn-nāșir, the scribe is Nabû-zēr-ibni/Rihētu// Sîn-nāșir. Nbk 281: the debtor is Nabû-aḩhē-iddin/Nabû-kēšir//Naggāru, the scribe is Bēl-zēr-ibni/Nabûkēšir//Naggāru.

38 VS 4 10: Bēl-uballiț/Mīnu-ana-Bēl-dannu//Nūr-Šamaš is both debtor and scribe. Dillard 1975 FLP 1522 : the debtor and the scribe is Nabû-ēțir-napšāti/Nabû-šum-iškun.

39 The tablet was first autographed by G. Bertin by the end of $19^{\text {th }}$ century, but his work remained unpublished. 


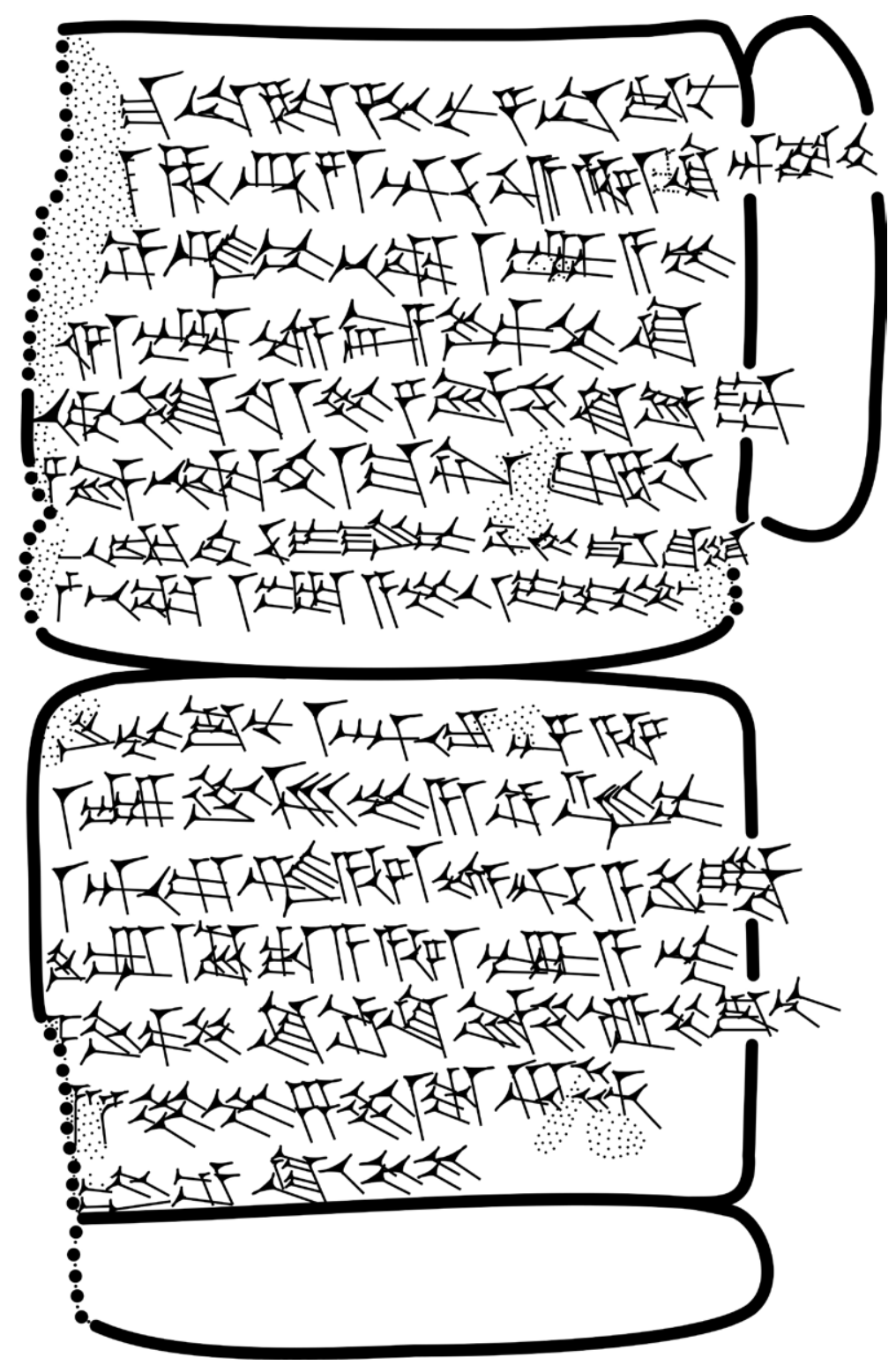

FIGURE 1. BM 31230. ㄷ Zs. J. Földi

\section{Translation}

${ }^{1}$ Five minas of ginnû-silver, which (is used) in trading (lit. 'giving and receiving'), (are) owed to Marduk-nāșir-apli, son of Itti-Marduk-balāțu, ${ }^{3}$ descendant of Egibi by Nabû-apla-iddin, son of Nabû-ētir, descendant of Isinnāya.

${ }^{5}$ From the $1^{\text {st }}$ day of Addaru and! (text: 'with') Nisannu each month one shekel of silver per one mina (i.e., 20\% interest) ${ }^{7}$ will accrue against him. (This is) apart from (another) debt which (is) owed by Nabû-apla-iddin and Iqūpu.

${ }^{9}$ Witnesses: Nergal-ēțir, son of Nabû-ahhēe-iddin, descendant of Egibi; ${ }^{11}$ Nergal-ušallim, son of Mušēzib-Marduk, descendant of Nappāhnu.

Scribe: Bulțāya, son of Nabû-apla-iddin, ${ }^{13}$ descendant of Isinnāya.

(Written in) Babylon, (on the) $4^{\text {th }}$ day of intercalary Addaru, the $5^{\text {th }}$ year (of the reign) of Darius (I), ${ }^{15} \mathrm{king}$ of Babylon and (of) the lands. 


\section{Notes}

(1-2) Since there is little room on the tablet before the signs MA.NA, I expect only one sign, which must be a figure. Less than seven months passed since the date of Dar 170, thus I do not suppose that the sum of the loan became lower. However, it cannot be one mina more either, because of the rate of interest 20\%. (On account of the months that passed, at least 30 shekels of silver could be added to the five minas, which would result in more signs). Therefore, the sum of the loan is restored from Dar 170 line 1.

The second contract (BM 31230) was a renewed agreement, the sum of the loan was handed over for seven months. I think this is the reason why the scribe omitted the explicit fineness of silver (875\% with Dar 170, line 1: kaspu ša ina 1 šiqil bitqa "silver of 1/8 alloy"). As the standard fineness of ginnû-silver was $875 \% 0,{ }^{40}$ it was sufficient to name the main characteristics of the silver.

(3-4) Apart from Dar 170 and BM 31230, the debtor Nabû-apla-iddin/Nabû-ētiir//Isinnāya is not known to have had any previous connection with the Marduk-nāṣir-apli archive. ${ }^{41}$

(5-7) This is an extended interest clause and it consists of two elements. The first element in line 5 stipulated the accurate day, from which on the interest had to be accrued, or paid. It seems that the beginning of the interest period of a loan did not ensue in many cases from the date of the text. According to the variants of this clause, the interest could accrue 1) from the same day as the date of the loan contract, 2) from the first day following the date of the loan contract, 3) from the first day of one of the months following the month in the date of the loan contract ${ }^{42} 4$ ) or in some cases it began antedated, i.e. before the date of the loan contract. ${ }^{43}$ However, the formulation attested in BM 31230 line 5, naming two months, is previously unattested and so far unique in the Neo-Babylonian written material. The second element in lines 6-7 was the common interest clause, which is identical with Dar 170 lines 5-7.

(7-8) Since the debtor in Dar 170 was only Nabû-apla-iddin/Nabû-êtir//Isinnāya, and the debt note, which BM 31230 in the elat-clause in lines 7-8 refers to had two debtors, namely Nabû-apla-iddin and Iqūpu, these lines cannot refer to Dar 170, but another loan contract. Presumably to the same loan as the one mentioned in Dar 170 lines 7-8.

(9-11) One of the two witnesses, Nergal-ušallim/Mušēzib-Marduk//Nappāhnu appeared in the first loan as well.

BM 31230 is a renewal of the original Dar 170 loan made almost seven months earlier. There is no change in the contracting parties, nor any new clause added to the document, and the sequence of clauses remained unchanged as well. The two texts only differ in the following points: the second text explains silver fineness in a briefer manner, while the clause on the interest rate is explained in more detail, and there is a second debtor identified in the elat-clause. Despite these slight changes, the agreement remained fundamentally the same. The creditor and the debtor were the same individuals as before, the amount of the loan was probably the same, the interest imposed on the loan was the same, and both texts made a reference to another loan. Therefore, the question arises as to why the original loan was rewritten. The answer must lie in the slight differences mentioned above. The shorter description of silver fineness actually referred to the same type of silver, so this explanation can be ruled out. The new person specified in the elatclause is not included as a party in either text. Consequently, the only reason why the loan was

40 Vargyas 2001, 24; Jursa et al. 2010, 481.

41 See Abraham 2004.

42 The interest could accrue deferred from the first, second, third etc., until the eleventh month after the date of the conclusion of agreement, see Csabai 2018, 19.

43 Csabai 2018. 
rewritten must have been the modified and expanded clause of interest. In line 5 the text reveals that the loan bore a $20 \%$ yearly interest rate, starting on the first day of month Addaru and Nisannu. This is an otherwise unprecedented case among the Neo-Babylonian and Achaemenid interest-bearing loans. Normally, the interest period began on the first day of a certain month, and save tablet BM 31230, there are no other sources specifying two months with regard to the starting point of the interest period. Furthermore, these were two consecutive months being the last and the first month of the Babylonian year. This brings up the question why both months were mentioned in the clause if they were consecutive ones, and if the interest started to run in Addaru and the same conditions applied for the following month as well which was Nisannu. This phenomenon could be explained by the use of different interest rates for the two consecutive months. However, this possibility can be ruled out because there is only one and the same rate of interest set out in both documents. Since the interest ran in both months, and the loan bore the same interest in both months, it should have been sufficient to set out only one month in the clause - but it was not the case. The reason for specifying two months in the interest clause is thus still unclear.

The examination of the date of BM 31230 may clarify the issue. The tablet was written in intercalary Addaru. There are texts from the first millennium B.C. showing that an intercalary month could be inserted in the calendar not only after, but before the regular Addaru month, too. ${ }^{44} \mathrm{How}$ ever, this seems to have been the case only in the Neo-Babylonian period. According to Ossendrijver, there was no intercalary Addaru preceding the regular Addaru in the Achaemenid period. ${ }^{45}$ This rules out the possibility that the intercalary Addaru in BM 31230 preceded the regular Addaru month.

The loan was renewed after almost seven months with the same terms and conditions, including the same interest rate of $20 \%$, annually. The conditions were the same, therefore the renewal of the debt note must have been motivated by the insertion of an intercalary month. The interest did not start to run on the date of BM 31230, nor on the first day of the intercalary month (i.e. antedated), ${ }^{46}$ nor on any other day of the intercalary month. Rather, it started to run on the first day of the preceding month Addaru and again started to run on the first day of the following month Nisannu, both with the same interest rate of $20 \%$ as it was also specified in the original promissory note. Therefore, we may come to the conclusion that the debtor was not required to pay interest for intercalary Addaru. ${ }^{47}$

If the interest was to be paid for the intercalary month, (a) it should have started to run on the first day of preceding Addaru, but Nisannu should not have been named, or (b) it should have started to run on the first day of the intercalary Addaru or (c) on the very date of BM 31230, but in this case the other two months need not have been specified. Consequently, this raises the question why the agreement did not simply stipulate that interest was to be paid from the first day of Nisannu. In my opinion, it is no accident that two months were included in the clause. The reason for this is that the new contract was not a mere renewal but rather the modification of the original. In case of a renewal, the conditions of the first loan became invalid and were replaced

44 See San Nicolò 1933. His sources were supplemented by Kleber 2008, 267 and n. 752; but cf. most recently Ossendrijver 2018.

45 As it was pointed out by Ossendrijver 2018, 138-139. However, Ossendrijver's scrupulous study is concerned with the last years of Darius I and with the reigns of the following Achaemenid rulers. He proposes that 19-year cycles can be observed from the $10^{\text {th }}$ year of Xerxes on (but the use of intercalary Ulūlu was not regular). Since Britton's (2002, 30-36) findings showed the irregular use of the 19-year cycle during the reign of Cyrus and Cambyses, based on Ossendrijver's and Britton's findings, I believe that BM 31230 was written in intercalary Addaru following the regular Addaru.

$46 \quad$ Csabai 2018

47 In line 5, an alternative translation 'from the $1^{\text {st }}$ day of Addaru with Nisannu', would result in the same meaning. 
by new ones. However, the conditions of the old agreement remained effective until the date of its renewal. Dar 170 stipulated an interest rate of $20 \%$ for a silver loan of five minas that had to be paid monthly during the interest period. The new agreement was made on the fourth day of the intercalary month; therefore, the above interest should generally have been expected to be accrued in that month as well.

Furthermore, there is another significant feature of BM 31230. It was written on the fourth day of the month which is at the beginning of the month. This suggests that the interest of the loan started to run at the beginning of the month, so the new debt note had to be concluded before the monthly interest was added to the debt. The debtor would avoid this interest payment. I wish to address another issue with regard to the loan by examining the economic reasons that led to the modification of the original agreement. The modification of the original note was motivated by the enormous amount of the loan which was 300 shekels. This amount is the equivalent of the total annual wage of about five to ten people in the age of Darius $\mathrm{I}^{48}$ The amount of the loan's monthly interest is also a large sum: five shekels. This was the pressing reason why the debtor (and the scribe who was the debtor's son) requested the modification of the agreement when they became aware of the insertion of the intercalary month.

However, only a mutual agreement could lead to this situation between the creditor(s) and debtor(s). Strictly speaking, the permission of the creditor(s) was mandatory. The result of a successful deal can be observed in BM 31230.

The effort to avoid an extra interest payment due to the insertion of an intercalary month, as represented by BM 31230, is not a unique case in the Neo-Babylonian period. If I am correct there is at least one more occasion of the phenomenon. We know another example from the reign of Nebuchadnezzar II, although in this case the loan was not written in the intercalary month itself. B. Funck published and commented on three promissory notes that are of interest here. ${ }^{49}$ They represent a debt note bearing a $20 \%$ rate of interest, recorded in the $3^{\text {rd }}, 4^{\text {th }}$ and $7^{\text {th }}$ years of Nebuchadnezzar II. ${ }^{50}$ Among these years, there was an intercalary Ulūlu in the $7^{\text {th }}$ year of Nebuchadnezzar II. The first promissory note ${ }^{51}$ about 15 shekels of silver was written on the $15^{\text {th }}$ of Addaru (month XII), and the loan bore a $20 \%$ of interest starting to run on the $20^{\text {th }}$ of the same month..$^{52}$ The second record, Nbk 39 was written again in Addaru on an uncertain day of the month, and the $20 \%$ of interest was accrued from an uncertain day of the same month. ${ }^{53}$ The loan was renewed in the $7^{\text {th }}$ year of Nebuchadnezzar II. The conditions of the new agreement ${ }^{54}$ did not change, the sum remained 15 shekels of silver, and it bore a 20\% interest. However, in this case the text was not written in Addaru, but in Ulūlu (month VI), ${ }^{55}$ and the $20 \%$ interest did not start to run on a day of the same month as it was the case in the two preceding loans, but from the month of Tašritu

48 On Neo-Babylonian and Achaemenid wages see Jursa et al. 2010, 669-728; most recently Jursa 2015, with references. For the value of the Babylonian wages in relation of the standard of living see Pirngruber 2016.

49 Nbk 34 (= Liv 5); Nbk 39 and Nbk 60 (= Liv 141). See Funck 1982, 51-52.

50 The creditor was Kudurru/Iqī̄̌āya, the debtor was Mukīn-zēri/Pir'u in Nbk 34. In Nbk 39 there were two debtors, Kīnāya(=Mukīn-zēri)/Pir'u and his wife Bu'iti, and the latter appears alone in the third text Nbk 60 . After Funck $(1982,52)$ the main reason of the two novations was the change of the debtors.

$51 \quad$ Nbk 34.

52 Nbk 34: lines 3-6 and 13.

53 The exact day is broken in the clause of the interest, as well as in the date, but in both cases the name of the month is preserved.

54 Nbk 60.

55 Nbk 60: lines 13-14. 
(month VII) onwards. ${ }^{56}$ However, this month was not the following month, but the second one following the conclusion of the agreement, because of the insertion of an intercalary Ulülu (month VI2). Again, to avoid the payment of interest for the intercalary month might be the reason why the agreement was renewed in Ulūlu. The interest for the regular Ulūlu was still valid in line with the previous debt agreement. The main clauses of the previous debt agreement(s) remained unchanged in the terms and conditions of the new agreement, but the fact, that according to the conditions of the new contract, the payment of the interests falls on the month of Tašritu can lead to the conclusion, that the creditor permitted the debtor not to pay interest during the intercalary month Ulūlu between the month of the contract and Tašrītu. Since the loan was renewed on the occasion of the insertion of an intercalary month, the changes in the parties were realized, as well. ${ }^{57}$

The renewal in the regular Ulūlu just before the intercalary month can underline the theory of Földi on the occupation- and vacancy-clauses of Old Babylonian house rental contracts, that intercalary months were at least sometimes anticipated by the ancient Babylonians, i.e. already in the month preceding the intercalary month. ${ }^{58}$

In conclusion, the cuneiform texts investigated here can not verify on the whole either of the two concepts mentioned. The above findings shed light on how interest payments were construed with regard to intercalary months in the Neo-Babylonian period. In years with intercalation debtors were required to pay interest for thirteen months, which was calculated not by changing the calculation of paying $1 / 12$ of interest monthly to paying retroactively $1 / 13$ of it, ${ }^{59}$ but by paying 13/12 of the interest. This statement is corroborated by other promissory notes made in any intercalary month, as none of the documents stipulated the exclusion or the extraordinary status of an intercalary month. This point is further proven by BM 31230 and probably by Nbk 60 that was only concluded to avoid the payment of an additional monthly interest. The effort to avoid an additional interest portion shows that otherwise an extra (a thirteenth 1/12) interest was accrued on the debt in the intercalary month of an intercalary year.

\section{Acknowledgments}

I gratefully acknowledge the permission of the Trustees of the British Museum to study and publish BM 31230. I wish to express my special thanks to Cornelia Wunsch and Enrique Jiménez who kindly provided me with excellent photographs of the tablet. I am deeply indebted to Zsombor Földi, who prepared the autograph of BM 31230, and made many helpful suggestions on an earlier draft of my paper. This research was funded by the European Union and the Hungarian State, co-financed by the European Social Fund in the framework of TÁMOP-4.2.4.A/2-11-1-2012-0001 Program. A shorter version of this paper was recently published in Hungarian. ${ }^{60}$

\section{References cited}

Abraham, K. 2004: Business and Politics under the Persian Empire. The Financial Dealings of Marduk-nāṣir-apli of the House of Egibi (521-487 B.C.E.). Bethesda.

\footnotetext{
56 Nbk 60: lines 3-5.

57 As Funck 1982, 52 suggested.

58 See Földi 2009, 19 and 22. Unfortunately, a similar clause is not known among the Neo-Babylonian house rental contracts, see most recently Zawadzki 2018, especially 57-58.

59 This method really would perturb the usual payment terms.

60 Csabai 2019
} 
BE 8/1: Clay, A. T. 1908: Legal and Commercial Transactions, Dated in the Assyrian, Neo-Babylonian and Persian Periods, Chiefly from Nippur. (The Babylonian Expedition of the University of Pennsylvania 8/1) Philadelphia.

Britton, J. P. 2002: Predictions of Lunar Phenomena in Babylonian Astronomy. In: StEELE, J. M. - IMHAUSEN, A. (eds.): Under One Sky: Astronomy and Mathematics in the Ancient Near East. (Alter Orient und Altes Testament 297) Münster, 5-20.

CoRfù, N. A. 2010: Die sogenannten achaimenidischen Bogenschützenmünzen - Die Herkunft von Dareikoi und Sigloi. Archäologische Mitteilungen aus Iran und Turan 42, 165-206.

CsabaI, Z. 2008: Verbrauchsdarlehen in Babylonien im 1. Jtsd. v. Chr. Eine Vorstudie. In: Vargyas, P. - SzABó, Á. (eds.): Cultus Deorum Studia Religionum ad Historiam. Vol. I. De Oriente Antiquo et Regione Danuvii Praehistorica in Memoriam István Tóth. (Ókortudományi Dolgozatok 1) Pécs, 203-218.

CsabaI, Z. 2018: Antedated Paying of Interest in the Neo-Babylonian and Achaemenid Periods. In: GRÜLL, T. (ed.): Mobility and Transfer. Studies on Ancient Economy. (Ancient Near Eastern and Mediterranean Studies 3) Pécs - Budapest, 17-34.

CsABAI, Z. 2019: Babilóniai kölcsönök kezelése szökőhónapokban [Babylonian Loans in Intercalary Months]. Pontes 2, 11-30.

CSEKe, H. 2014: The Economic Determination of the Changing Interests. A Survey Based on the Loan Documents of the Neo-Babylonian Sîn-uballit Archive. In: CsABAI, Z. (ed.): Studies in Economic and Social History of the Ancient Near East in Memory of Péter Vargyas. (Ancient Near Eastern and Mediterranean Studies 2) Pécs - Budapest, 557-578.

Cyr: Strassmaier, J. N. 1890: Inschriften von Cyrus, König von Babylon (538-529 v. Chr.). (Babylonische Texte 7) Leipzig.

Dar: Strassmaier, J. N. 1897: Inschriften von Darius, König von Babylon (521-486 v. Chr.). (Babylonische Texte 10-12) Leipzig.

Dillard, R. B. 1975: Neo-Babylonian Texts from the John Frederick Lewis Collection of the Free Library of Philadelphia. PhD dissertation (Dropsie University). [MS].

ElLIs, M. DE J. 1984: Neo-Babylonian Texts in the Yale Babylonian Collection. Journal of Cuneiform Studies 36, 1-63. https://doi.org/10.2307/1360010

FöldI, Zs. J. 2009: Rībatum. The Archive of a Priestess from Old Babylonian Sippar / Rībatum. Egy papnó archívuma az óbabilóni Szipparból. BA thesis (ELTE Budapest) [MS].

Funck, B. 1982: Studien zur sozialökonomischen Situation Babyloniens im 7. und 6. Jahrhundert v. u. Z. In: KLENGEL, H. (ed.): Gesellschaft und Kultur im alten Vorderasien. (Schriften zur Geschichte und Kultur des Alten Orients 15) Berlin, 47-67.

Hunger, H. 1970: Das Archiv des Nabû-ušallim. Baghdader Mitteilungen 5, 193-204.

Hunger, H. 1977: Kalender. In: EdzArd, D. O. (ed.): Reallexikon der Assyriologie und Vorderasiatischen Archäologie, Band 5. Berlin - New York, 297-303.

Hunger, H. - Pingree, D. 1999: Astral Sciences in Mesopotamia. (Handbuch der Orientalistik I, 44) Leiden Boston - Köln. https://doi.org/10.1163/9789004294134

JoAnNÈs, F. 2000/2002 (online): Strassmaier, Darius 170 . http://www.achemenet.com/fr/ item/?/sources-textuelles/textes-par-langues-et-ecritures/babylonien/archives-egibi/1655924 (last accessed: $17^{\text {th }}$ of October 2019).

JuRsa, M. 1998: Der Tempelzehnt in Babylonien vom siebenten bis zum dritten Jahrhundert v. Chr. (Alter Orient und Altes Testament 254) Münster.

JuRSA, M. 2002: Debt and Indebtedness in the Neo-Babylonian Period: Evidence from the Institutional Archives. In: Hudson, M. - Van De Mieroop, M. (eds.): Debt and Economic Renewal in the Ancient Near East. (The International Scholars Conference on Ancient Near Eastern Economies 3) Bethesda, 197-219.

JurSA, M. ET AL. 2010: Aspects of the Economic History of Babylonia in the First Millennium B.C. Economic Geography, Economic Mentalities, Agriculture, the Use of Money and the Problem of Economic Growth. (Alter Orient und Altes Testament 377 = Veröffentlichungen zur Wirtschaftsgeschichte Babyloniens im 1. Jahrtausend v. Chr. 4) Münster.

Jursa, M. 2015: Labor in Babylonia in the First Millennium BC. In: Steinkeller, P. - Hudson, M. (eds.): Labor 
in the Ancient World. (The International Scholars Conference on Ancient Near Eastern Economies 5) Dresden, 345-396.

Kessler, K. 1991: Uruk. Urkunden aus Privathäusern. Die Wohnhäuser westlich des Eanna-Tempelbereichs, Teil I. Die Archive der Söhne des Bēl-ušallim, des Nabû-ušallim und des Bēl-supê-muhur. (Ausgrabungen in Uruk-Warka, Endberichte 8) Mainz am Rhein.

KLeBER, K. 2008: Tempel und Palast. Die Beziehungen zwischen dem König und dem Eanna-Tempel im spätbabylonischen Uruk. (Alter Orient und Altes Testament 358) Münster.

Liv: Strassmaier, J. N. 1885: Die babylonischen Inschriften im Museum zu Liverpool nebst andern aus der Zeit von Nebukadnezzar bis Darius. Leiden.

NbK: Strassmaier, J. N. 1889: Inschriften von Nabochodonosor, König von Babylon 604-561 v. Chr. (Babylonische Texte 5-6) Leipzig.

Nbn: Strassmaier, J. N. 1889: Inschriften von Nabonidus, König von Babylon 555-538 v. Chr. (Babylonische Texte 1-4) Leipzig.

OECT 12: JoAnNÈs, F. 1990: Les tablettes néo-babyloniennes de la Bodleian Library conservées à l'Ashmolean Museum. (Neo-Babylonian Tablets in the Asmolean Museum). (Oxford Editions of Cuneiform Texts 12) Oxford.

Oelsner, J. 2001: Neo-Babylonian Period. In: Westbrook, R. - Jasnow, R. (eds.): Security for Debt in Ancient Near Eastern Law. (Culture and History of the Ancient Near East 9) Leiden - Boston - Köln, 289-305.

Oelsner, J. - Wells, B. - Wunsch, C. 2003: Neo-Babylonian Period. In: Westbrook 2003a, 911-974. https://doi. org/10.1163/9789047402091_027

Ossendrijver, M. 2018: Babylonian Scholarship and the Calendar during the Reign of Xerxes. In: WAERzEGgers, C. - SeIre, M. (eds.): Xerxes and Babylonia. The Cuneiform Evidence. (Orientalia Lovaniensia Analecta 277) Leuven, 135-163.

Petschow, H. 1956: Neubabylonisches Pfandrecht. Berlin.

Pirngruber, R. 2016: The Value of Silver: Wages as Guides to the Standard of Living in First Millennium BC Babylonia. In: Kleber, K. - Pirngruber, R. (eds.): Silver, Money and Credit. A Tribute to Robertus J. van der Spek on the Occasion of His $65^{\text {th }}$ Birthday. (Publications de l'Institut historique et archéologique néerlandais de Stamboul 128) Leiden, 107-118.

Powell, M. A. 1999: Wir müssen unsere Nische nützen: Monies, Motives, and Methods in Babylonian Economics. In: Dercksen, J. G. (ed.): Trade and Finance in Ancient Mesopotamia. (MOS Studies 2 = Publications de l'Institut historique et archéologique néerlandais de Stamboul 84) Leiden, 5-24.

Ratzon, E. 2016: Early Mesopotamian Intercalation Schemes and the Sidereal Month. Mediterranean Archaeology and Archaeometry 16, 143-151.

SAN Nicolò, M. 1933: Parerga Babyloniaca X-XI. Archiv Orientální 5, 284-302.

SHIfF, L. B. 1988: Neo-Babylonian “Interest-Free” Promissory Notes. Journal of Cuneiform Studies 40, 187194. https://doi.org/10.2307/1359661

SkAIst, A. 1994: The Old Babylonian Loan Contract. Its History and Geography. (Bar-Ilan Studies in Near Eastern Languages and Culture) Ramat Gan.

Slanski, K. 2003: Middle Babylonian Period. In: Westbrook 2003a, 485-520. https://doi. org/10.1163/9789047402091_012

SteEle, J. M. 2007: The Length of the Month in Mesopotamian Calendars of the First Millennium B.C. In: Steele, J. M. (ed.): Calendars and Years: Astronomy and Time in the Ancient Near East. Oxford, 133-148.

STEELE, J. M. 2011: Making Sense of Time: Observational and Theoretical Calendars. In: RADNER, K. - RoBSON, E. (eds.): The Oxford Handbook of Cuneiform Culture. (Oxford Handbooks in Classics and Ancient History) Oxford, 470-485. https://doi.org/10.1093/oxfordhb/9780199557301.013.0022

Stratford, E. 2015: Successor Eponyms, Debt Notes, Intercalation, and the Old Assyrian Calendar during Kültepe Level II: A Critical Reappraisal. Journal of Near Eastern Studies 74, 301-324. https://doi. org/10.1086/682062

TCL 12: Contenau, G. 1927: Contrats néo-babyloniens I. de Téglath-phalasar III à Nabonide. (Textes Cunéiformes, Musée du Louvre 12) Paris. 
TMH 2/3: KRÜCKMANN, O. 1933: Neubabylonische Rechts- und Verwaltungstexte. (Texte und Materialien der Frau Professor Hilprecht Collection of Babylonian Antiquities im Eigentum der Universität Jena 2/3) Leipzig.

VAn De Mieroop, M. 1995: Old Babylonian interest rates: Were they annual? In: VAn Lerberghe, K. - Schoors, A. (eds.): Immigration und Emigration within the Ancient Near East. Festschrift E. Lipiński. (Orientalia Lovaniensia Analecta 65) Leuven, 357-364.

VAn De Mieroop, M. 2005: The Invention of Interest: Sumerian Loans. In: Goetzmann, W. N. - Rouwenhorst, K. G. (eds.): The Origins of Value. The Financial Innovations that Created Modern Capital Markets. Oxford, 17-30; 359-361.

VARgYAs, P. 1999: Kaspu ginnu and the Monetary Reform of Darius I. Zeitschrift für Assyriologie und vorderasiatische Archäologie 89, 247-268. https://doi.org/10.1515/zava.1999.89.2.247

VARgYaS, P. 2000: Babylonian Interest Rates: Weren’t They Annual? In: Graziani, S. (ed.): Studi sul Vicino Oriente antico dedicati alla memoria di Luigi Cagni. (Istituto Universitario Orientale, Dipartimento di Studi Asiatici, Series Minor 61) Napoli, 1095-1105.

VARgYAs, P. 2001: A History of Babylonian Prices in the First Millennium B.C. Vol. I. Prices of the Basic Products. (Heidelberger Studien zum Alten Orient 10) Heidelberg.

VS 3: Ungnad, A. 1907: Vorderasiatische Schriftdenkmäler der königlichen Museen zu Berlin. Heft 3. Leipzig.

VS 4: UnGnad, A. 1907: Vorderasiatische Schriftdenkmäler der königlichen Museen zu Berlin. Heft 4. Leipzig.

Westbrook, R. (ed.) 2003a: A History of Ancient Near Eastern Law (Handbuch der Orientalistik I, 72/1-2) Leiden - Boston. https://doi.org/10.1163/9789047402091_002

Westbrook, R. 2003b: Old Babylonian Period. In: Westbrook 2003a, 361-430. https://doi. org/10.1163/9789047402091_010

Wunsch, C. 1999a: Handel und Wandel in Babylon: Die Geschäfte der Familie Egibi. In: SEIPEL, W. ET AL. (eds.): Von Babylon bis Jerusalem. Die Welt der orientalischen Königsstädte II. Milano, 325-333.

Wunsch, C. 1999b: Neubabylonische Urkunden: Die Geschäftsurkunden der Familie Egibi. In: RENGER, J. (ed.): Babylon: Focus mesopotamischer Geschichte, Wiege früher Gelehrsamkeit, Mythos in der Moderne. (Colloquien der Deutschen Orientgesellschaft 2) Saarbrücken, 343-364.

Wunsch, C. 2000: Das Egibi-Archiv. I. Die Felder und Gärten (Cuneiform Monographs 20 A-B) Groningen.

Wunsch, C. 2002: Debt, Interest, Pledge and Forfeiture in the Neo-Babylonian and Early Achaemenid Period: The Evidence from Private Archives. In: Hudson, M. - VAn De Mieroop, M. (eds.): Debt and Economic Renewal in the Ancient Near East. (The International Scholars Conference on Ancient Near Eastern Economies 3) Bethesda, 221-255.

Wunsch, C. 2007: The Egibi family. In: LeIck, G. (ed.): The Babylonian World. London - New York, $236-247$.

YOS 19: BEAUlieu, P-A. 2000: Legal and Administrative Texts from the Reign of Nabonidus. (Yale Oriental Studies, Babylonian Texts 19) New Haven - London.

ZaWAdZKI, S. 2018: The Rental of Houses in the Neo-Babylonian Period (VI-V. Centuries BC). Warsaw. 


\section{HUNGARIAN ASSYRIOLOGICAL HAR REVIEW}

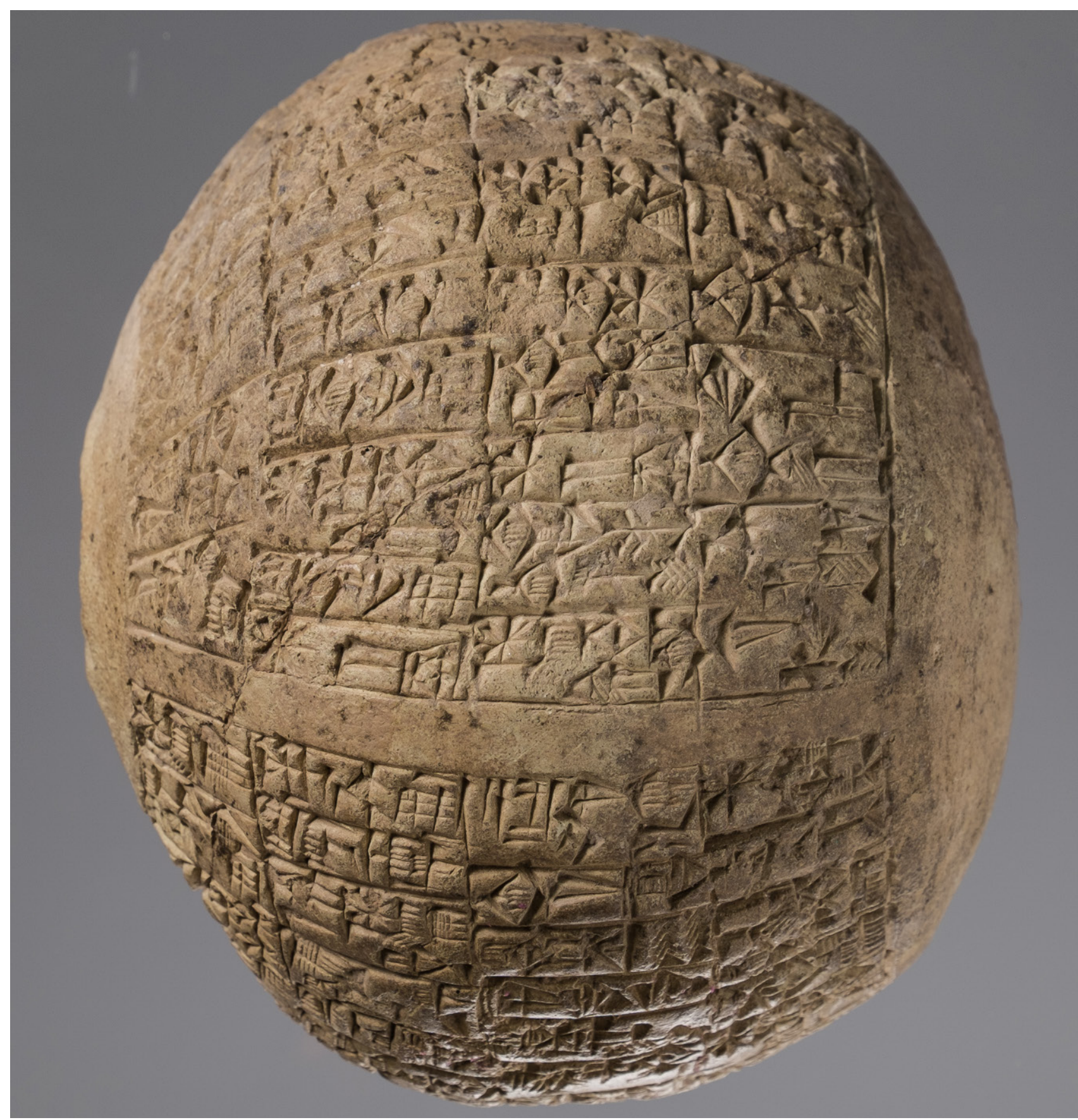

VOLUME 1 | ISSUE 1 | 2020 
ON THE COVER:

Jar-like clay object (T.3860),

Sulaymaniyah Museum. See pp. 21-39.

Photo: Suleymaniah Museum 


\section{HUNGARIAN ASSYRIOLOGICAL REVIEW

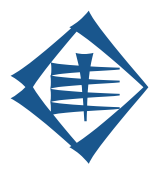 \\ VOLUME 1, ISSUE 1 \\ 2020}

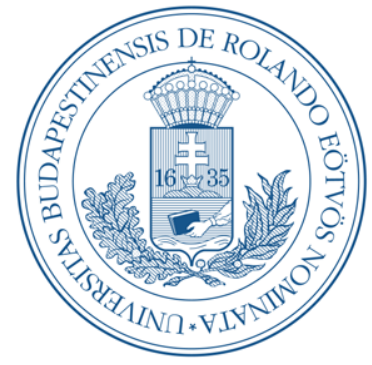

Institute of Archaeological Sciences

Institute of Ancient and Classical Studies

Eötvös Loránd University

Budapest 


\section{HUNGARIAN}

\section{HAR - Hungarian Assyriological Review}

Journal of the Institute of Archaeological Sciences and the Institute of Ancient and Classical Studies (Department of Assyriology and Hebrew Studies), Eötvös Loránd University, Budapest, Hungary.

HAR is a peer-reviewed electronic journal (HU ISSN 2732-2610) published in two issues per year. The journal covers the philology and the archaeology of the Ancient Near East, publishing research articles, brief notes, and field reports.

Papers in HAR are published under the platinum open access model, which means permanent and free access in downloadable format (pdf) for readers and no publication fees for authors. The issues can be both downloaded for free and ordered as printed volumes at own cost.

For article submission guidelines, see https://harjournal.com/author-guidelines/

\section{Editorial board}

Editor-in-chief (szerkesztésért felelös személy):

Gábor Kalla, Eötvös Loránd University, Budapest

\section{Associate editors:}

Zsombor J. Földi, Ludwig-Maximilians-Universität, München

Zsolt Simon, Ludwig-Maximilians-Universität, München

\section{Editorial board:}

Tamás Dezső, Eötvös Loránd University, Budapest

Gábor Zólyomi, Eötvös Loránd University, Budapest

Technical editor:

Attila Király

Publisher (kiadó és kiadásért felelös személy):

Gábor Kalla, Eötvös Loránd University, Budapest

\section{Registered office (a kiadó székhelye):}

Institute of Archaeological Sciences, Múzeum Krt. 4/B., 1088 Budapest, Hungary.

Email address: info@harjournal.com

\section{Design and typesetting:}

Attila Király (attila@litikum.hu)

using Noto font family by Google Inc., under the terms of the SIL Open Font License. 


\section{CONTENTS}

\section{Hungarian Assyriological Review}

\section{volume 1, issue 1, 2020}

Editorial

Zsombor J. Földi, Gábor Kalla, Zsolt Simon

Paratactic relative clauses in Sumerian

Gábor Zólyomi

An abbreviated version of En-metena 1 from the Sulaymaniyah Museum

Ardalan Khwshnaw - Gábor Zólyomi

Cuneiform Luwian =ku(wa): form and meaning

Zsolt Simon

The property of the city, the property of the king? A new fragment of YOS 12, 321

zsombor J. Földi

Intercalary Months and Interest-bearing Loans in Babylonia.

A Promissory Note from the Egibi Archive

Zoltán Csabai

Hungarian Assyriological Review

Author Guidelines 
